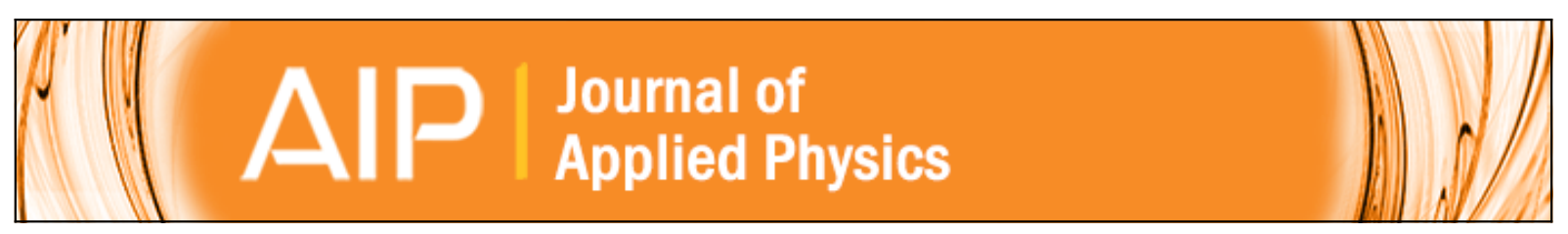

\title{
Precipitation of iron in multicrystalline silicon during annealing
}

A. Y. Liu and Daniel Macdonald

Citation: Journal of Applied Physics 115, 114901 (2014); doi: 10.1063/1.4868587

View online: http://dx.doi.org/10.1063/1.4868587

View Table of Contents: http://scitation.aip.org/content/aip/journal/jap/115/11?ver=pdfcov

Published by the AIP Publishing

\section{Articles you may be interested in}

Precipitated iron: A limit on gettering efficacy in multicrystalline silicon

J. Appl. Phys. 113, 044521 (2013); 10.1063/1.4788800

Deep-level photoluminescence due to dislocations and oxygen precipitates in multicrystalline $\mathrm{Si}$

J. Appl. Phys. 111, 113523 (2012); 10.1063/1.4728194

Iron distribution in silicon after solar cell processing: Synchrotron analysis and predictive modeling

Appl. Phys. Lett. 98, 162103 (2011); 10.1063/1.3575583

Understanding the distribution of iron in multicrystalline silicon after emitter formation: Theoretical model and experiments

J. Appl. Phys. 109, 063717 (2011); 10.1063/1.3553858

Impact of oxygen on carbon precipitation in polycrystalline ribbon silicon

J. Appl. Phys. 97, 033509 (2005); 10.1063/1.1847699

\section{A|P| $\left.\right|_{\text {Applied Physics }} ^{\text {Journal of }}$}

Journal of Applied Physics is pleased to announce André Anders as its new Editor-in-Chief 


\title{
Precipitation of iron in multicrystalline silicon during annealing
}

\author{
A. Y. Liü and Daniel Macdonald \\ Research School of Engineering, The Australian National University, Canberra ACT 0200, Australia
}

(Received 1 February 2014; accepted 4 March 2014; published online 17 March 2014)

\begin{abstract}
In this paper, the precipitation kinetics of iron in multicrystalline silicon during moderate temperature annealing are systematically studied with respect to annealing time, temperature, iron super-saturation level, and different types and densities of precipitation sites. The quantitative analysis is based on examining the changes in the concentrations and distributions of interstitial iron in multicrystalline silicon wafers after annealing at $400-700^{\circ} \mathrm{C}$. This is achieved by using the photoluminescence imaging technique to produce high-resolution spatially resolved images of the interstitial iron concentrations. The concentrations of interstitial iron are found to decrease exponentially with the annealing time. Comparison of the precipitation time constants of wafers annealed at different temperatures and of different initial interstitial iron concentrations indicates that higher levels of iron super-saturation result in faster precipitation processes. The impact of iron super-saturation on the precipitation kinetics becomes increasingly important at low levels of super-saturation, while its impact saturates at very high levels of super-saturation (above 1000). Some grain boundaries are shown to act as effective precipitation sites for iron during annealing, and the reduction in the interstitial iron concentrations in the intra-grain regions is found to be mainly due to precipitation at dislocations. Some important differences between the iron precipitation behaviour at the grain boundaries and at the intra-grain dislocations are discussed. The effect of hydrogenation of the multicrystalline silicon wafers on the apparent iron precipitation rate is also presented and discussed. (c) 2014 AIP Publishing LLC. [http://dx.doi.org/10.1063/1.4868587]
\end{abstract}

\section{INTRODUCTION}

Multicrystalline silicon (mc-Si) is a widely used material in the photovoltaic industry. It is known to contain a large amount of structural defects and impurities, which significantly reduce the solar cell efficiency. Iron $(\mathrm{Fe})$ is one of the most detrimental metallic impurities in mc-Si. ${ }^{1-3}$ It is also commonly found in $\mathrm{mc}-\mathrm{Si}$, originating mostly from the crucible, crucible lining and feedstock during ingot growth. ${ }^{4-6}$ The majority of iron in mc-Si is present in the form of precipitates, which are generally less harmful to the global carrier lifetime than the mobile, dissolved interstitial $\mathrm{Fe}$ atoms $\left(\mathrm{Fe}_{\mathrm{i}}\right)^{2,3}$ In addition, a low density of large precipitates is less detrimental than a high density of small precipitates, ${ }^{4}$ due to the fact that the surfaces of the precipitates are found to be the recombination active area. ${ }^{7}$

Reducing the negative impact of iron contamination in silicon, either by removing the dissolved iron atoms from the material bulk through external gettering, or by driving iron precipitation at heterogeneous defects within the material through internal gettering, is beneficial for solar cell efficiency. External gettering of iron by diffused regions of phosphorous, boron or aluminium at high temperatures 8 is commonly used in solar cell production. The efficacy of the external gettering process is further improved by an in-situ anneal at relatively low temperatures $\left(600-700^{\circ} \mathrm{C}\right)$ after the standard diffusion. ${ }^{8,9}$ Extensive research has been conducted to understand and optimise such external gettering processes. Also, internal gettering of iron by intentionally grown oxygen

\footnotetext{
a) Author to whom correspondence should be addressed. E-mail: anyao.liu@anu.edu.au
}

precipitates in Czochralski $(\mathrm{Cz})$ silicon is widely used in the electronic industry. ${ }^{10-13}$ However, limited research has been carried out to exploit the benefit of internal gettering in $\mathrm{mc}-\mathrm{Si}$ materials for photovoltaics. It has been reported that the effective minority carrier lifetime and the solar cell efficiency is improved after a relatively low temperature $\left(500-600^{\circ} \mathrm{C}\right)$ annealing process for $\mathrm{mc}-\mathrm{Si}$ samples with phosphorous emitters, ${ }^{14-16}$ due to a combined effect of external and internal gettering. ${ }^{15,16}$ Krain et al. ${ }^{17}$ studied the internal gettering of iron at $300-500{ }^{\circ} \mathrm{C}$ in $\mathrm{mc}-\mathrm{Si}$ wafers without phosphorous emitters, and reported reductions in the interstitial iron concentrations by more than one order of magnitude. However, a quantitative examination of the spatial distribution of Fe precipitation was not performed in this study. ${ }^{17}$ In our previous work, ${ }^{18}$ a much slower precipitation rate than those reported in Krain et al. ${ }^{17}$ was found in mc-Si wafers. The crystallographic defects in mc-Si material, such as grain boundaries (GBs) and dislocations, are known to act as gettering sites for interstitial $\mathrm{Fe}$ to precipitate at during ingot cooling. ${ }^{4,19,20}$ To our knowledge, the Fe precipitation kinetics at different types of crystallographic defects has not been examined in the literature. As the silicon solar cell industry is moving towards increasingly higher efficiency cells, it is necessary to explore the possible options to achieve better efficiency. An improved understanding of the Fe precipitation kinetics may be beneficial for the development of effective low-temperature internal gettering processes tailored to specific mc-Si materials.

This paper presents a systematic study of the Fe precipitation kinetics in multicrystalline silicon, with respect to annealing time, temperature, super-saturation level, and different types and densities of precipitation sites. Annealing 
temperatures in the range of $400-700{ }^{\circ} \mathrm{C}$ are examined. Two sets of mc-Si wafers of different initial interstitial Fe concentrations are used to study the effect of the Fe super-saturation level on the precipitation kinetics. The Fe precipitation kinetics at the grain boundaries and different intra-grain regions are separately analysed. This is achieved through the use of high resolution photoluminescence-based images ${ }^{21}$ of the interstitial Fe concentrations ${ }^{22}$ across mc-Si wafers. The effect of mc-Si bulk hydrogenation on the observed Fe precipitation kinetics is also discussed.

\section{EXPERIMENTAL DETAILS}

The multicrystalline silicon wafers used in this study were from a commercially grown boron-doped directionally solidified ingot. The wafers are $330 \mu \mathrm{m}$ thick and 12.5 $\times 12.5 \mathrm{~cm}^{2}$ in size. Two wafers were chosen for this study. They are located at $28 \%$ and $32 \%$ from the bottom of the ingot respectively. The resistivity of the two wafers is around $1.4 \Omega \mathrm{cm}$. As the two are not far apart within the vertical direction of the ingot, they demonstrate similar distributions of grain boundaries and dislocation clusters. However, a large difference in the interstitial iron concentrations $\left(\left[\mathrm{Fe}_{\mathrm{i}}\right]\right)$ is found for wafers from this part of the ingot, where the concentration of $\mathrm{Fe}$ diffused into the solid ingot from the crucible base drops rapidly, as shown in Ref. 23, which was based on the same ingot. One of the wafers has an $\left[\mathrm{Fe}_{\mathrm{i}}\right]$ of approximately $10^{13} \mathrm{~cm}^{-3}$ and the other of approximately $3 \times 10^{12} \mathrm{~cm}^{-3}$, and they will be referred to as high $\left[\mathrm{Fe}_{\mathrm{i}}\right]$ and low $\left[\mathrm{Fe}_{\mathrm{i}}\right]$ samples, respectively, in this paper. The wafers were diced into smaller pieces of $4.15 \times 4.15 \mathrm{~cm}^{2}$ in size. The average concentrations of interstitial $\mathrm{Fe}$ across the $4.15 \times 4.15 \mathrm{~cm}^{2}$ pieces vary by less than $30 \%$ from piece to piece. The small differences in the area-averaged $\left[\mathrm{Fe}_{\mathrm{i}}\right]$ across the pieces are due to the different spatial distributions of structural defects, which acted as the internal gettering sites during ingot cooling and thus resulted in slightly different final average dissolved Fe concentrations.

The wafers were chemically etched, cleaned, and then annealed in dry oxygen at $1000{ }^{\circ} \mathrm{C}$ for 45 min to grow silicon oxide layers for surface passivation. Oxide passivation was chosen as it remains stable during subsequent low temperature annealing steps, unlike silicon nitride passivation, for example. Annealing at $1000^{\circ} \mathrm{C}$ also uniformly distributes the interstitial $\mathrm{Fe}$ concentrations across the wafers, as shown in the Fe image in Fig. 1(a). The total Fe concentration of wafers from this part of the ingot, interpolated from the neutron activation analysis of the wafers from the same ingot, ${ }^{2}$ is on the order of $10^{14} \mathrm{~cm}^{-3}$. Therefore, a large fraction of Fe is in precipitated form. Some dissolution of this precipitated $\mathrm{Fe}$ is expected during such high temperature processes, ${ }^{24}$ however, our previous study ${ }^{18,25}$ on neighbouring wafers found that the amount of dissolution is not significant compared to the initial as-cut interstitial $\mathrm{Fe}$ concentrations on the order of $10^{12}-10^{13} \mathrm{~cm}^{-3}$. It was found that the neighbouring wafers in the as-cut state, either oxidised and removed from the furnace at $1000^{\circ} \mathrm{C}$, or oxidised at $1000^{\circ} \mathrm{C}$ followed by a $10^{\circ} \mathrm{C} / \mathrm{min}$ cool-down to $700^{\circ} \mathrm{C}$ before being removed from the furnace, all show similar average interstitial $\mathrm{Fe}$ (a) 0 hour annealing

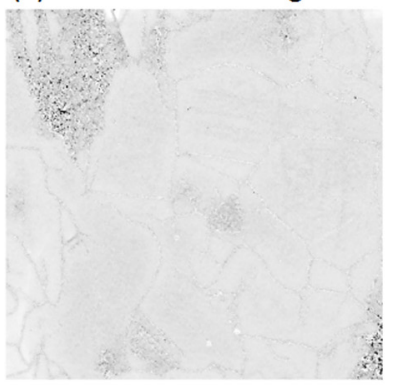

(b) 2.9 hours annealing

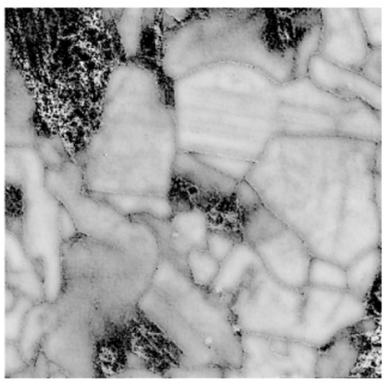

(c) 7.1 hours annealing

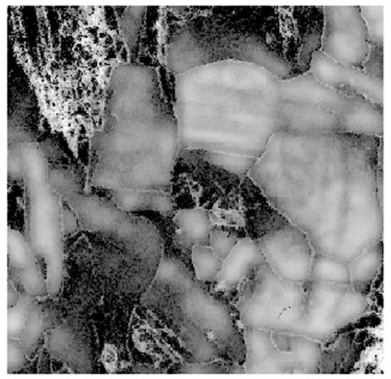

(d) 14.5 hours annealing

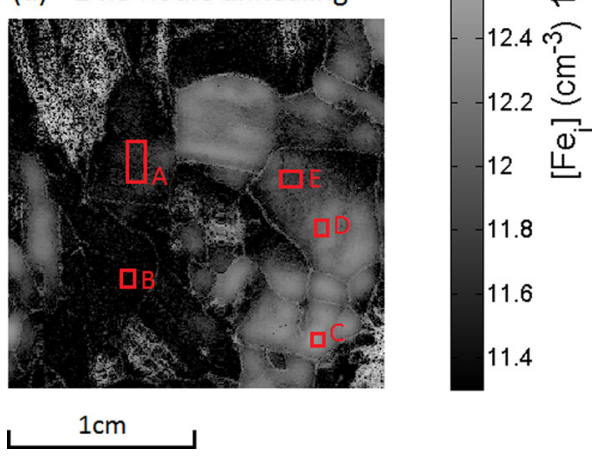

FIG. 1. Interstitial Fe images of the same wafer (a) after oxidation and before low temperature annealing, (b) after annealing at $500{ }^{\circ} \mathrm{C}$ for a cumulative time of $2.9 \mathrm{~h}$, (c) $7.1 \mathrm{~h}$, and (d) $14.5 \mathrm{~h}$. Comparison of the $\left[\mathrm{Fe}_{\mathrm{i}}\right]$ images shows that the $\mathrm{Fe}_{\mathrm{i}}$ concentrations are reduced with increasing annealing time. The five squares A-E labelled in image (d) are the intra-grain regions analysed in Fig. 9.

concentrations. It seems that the amount of $\mathrm{Fe}$ dissolution during the high temperature oxidation process and the amount of Fe precipitation during the cool-down to $700{ }^{\circ} \mathrm{C}$ were insignificant compared to the background concentrations of $\mathrm{Fe}$. As a result, the wafers used in this study were cooled down to $750{ }^{\circ} \mathrm{C}$ at a rate of $10^{\circ} \mathrm{C} / \mathrm{min}$ after the $1000^{\circ} \mathrm{C}$ oxidation step, before being removed from the furnace and left in an air flow to reach room temperature within minutes. The thermally grown silicon oxide layers are between $50-80 \mathrm{~nm}$ thick. 
To test the effect of hydrogenation on the measured interstitial $\mathrm{Fe}$ concentrations, one of the oxidised wafers received an HF dip to remove the silicon oxide layers, and was re-passivated with aluminium oxide films of around $20 \mathrm{~nm}$ using plasma-assisted Atomic Layer Deposition (ALD). The deposition process was carried out at $175^{\circ} \mathrm{C}$ for a total time of $1 \mathrm{~h}$.

Each wafer was then annealed at one temperature in the range of $400-700^{\circ} \mathrm{C}$, for various time intervals ranging from minutes to hours. Wafers from both sample sets, high and low initial $\left[\mathrm{Fe}_{\mathrm{i}}\right]$, were included for each temperature, to study the effect of the initial $\left[\mathrm{Fe}_{\mathrm{i}}\right]$ on the precipitation kinetics. The ambient gas during the low temperature anneals for the oxidised wafers was a mixture of $95 \%$ argon and $5 \%$ hydrogen, which we have found maintains the surface passivation of the $\mathrm{SiO}_{2}$ films. For the $\mathrm{Al}_{2} \mathrm{O}_{3}$ coated wafer, a nitrogen ambient was used for the low temperature anneals.

Float-zone single crystalline wafers were included in the processing steps to monitor the stability of the surface passivation layers, as any significant reduction in the surface passivation quality may affect the sensitivity of the PL-based iron images. The FZ-Si wafers were boron-doped p-type wafers with a resistivity of approximately $2 \Omega \mathrm{cm}$ and a thickness of $250 \mu \mathrm{m}$. Fig. 2 shows that the surface passivation of both silicon oxide and aluminium oxide layers is reasonably stable during annealing for extended times at $400^{\circ} \mathrm{C}$ and $700^{\circ} \mathrm{C}$. The magnitude of the minority carrier lifetime due to surface recombination (as reflected by the lifetime of the FZ-Si samples) is 2 orders of magnitude higher than the lifetime due to bulk recombination in the mc-Si wafers. Therefore, the observed changes in the surface passivation have little impact on the effective minority carrier lifetime of the mc-Si samples, and will not affect the iron images.

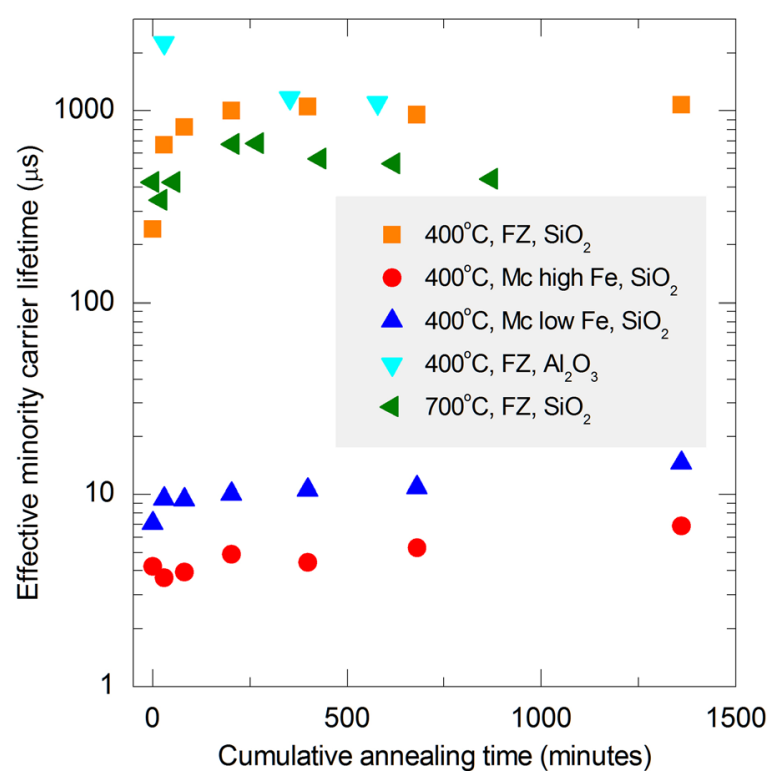

FIG. 2. Effective minority carrier lifetimes of multicrystalline and float-zone wafers annealed at $400^{\circ} \mathrm{C}$ or $700^{\circ} \mathrm{C}$ with respect to the cumulative annealing time. The excess carrier densities at which the minority carrier lifetimes were measured were at $1 \times 10^{15} \mathrm{~cm}^{-3}$ for the FZ wafers, $3 \times 10^{14} \mathrm{~cm}^{-3}$ for the high $\left[\mathrm{Fe}_{\mathrm{i}}\right] \mathrm{mc}-\mathrm{Si}$ wafer and $6 \times 10^{14} \mathrm{~cm}^{-3}$ for the low $\left[\mathrm{Fe}_{\mathrm{i}}\right] \mathrm{mc}-\mathrm{Si}$ wafer.
The interstitial $\mathrm{Fe}$ concentrations in the mc-Si wafers were measured after each thermal annealing step, by using an LIS-R1 photoluminescence imaging tool ${ }^{21}$ from BT Imaging for spatially resolved distributions of interstitial $\mathrm{Fe}$ concentrations. ${ }^{22}$ The wavelength of the illumination source is $808 \mathrm{~nm}$. A magnifying lens was used, giving an image pixel size of about $23 \mu \mathrm{m}$. The derivation of the $\mathrm{Fe}_{i}$ concentration is based on the well-established method of measuring the minority carrier lifetimes before and after the dissociation of the Fe-B pairs in silicon, ${ }^{26}$ via strong illumination in this experiment. The PL-based lifetime images were calibrated via an in-built Quasi-Steady-State PhotoConductance (QSSPC) tester from Sinton Instruments. ${ }^{27}$ A point spread function was applied to de-convolute image smearing caused by the lateral photon scattering within the Si-CCD camera. ${ }^{28}$ The samples had planar, chemically polished surfaces, minimising the amount of light-trapping in the sample itself, which can also lead to a small degree of optical image smearing. As the minority carrier lifetimes of the tested samples are small, in the micro-second range, the effect of carrier diffusion smearing on the resulting $\left[\mathrm{Fe}_{\mathrm{i}}\right]$ images was found to be small. ${ }^{19}$ Separate QSSPC lifetime measurements were also used to measure the average minority carrier lifetimes of some of the mc-Si wafers, as an alternative method to ascertain the average concentrations of interstitial $\mathrm{Fe}$ obtained from the calibrated PL imaging technique.

In order to reveal the distributions of the structural defects in the mc-Si wafers, after the annealing experiment, the silicon oxide layers were etched off and some of the wafers were defect etched using the "MD1" etching recipe of Kashiwagi et al. ${ }^{29}$ The structural defects were revealed as etch pits on the wafers, and could be identified under a light microscope.

\section{RESULTS AND DISCUSSIONS}

Comparing images of the interstitial $\mathrm{Fe}$ concentrations of the same wafer before and after annealing at a low temperature (Fig. 1), it is evident that the $\mathrm{Fe}_{\mathrm{i}}$ concentrations are decreased with respect to the annealing time, and this reduction is not uniform across the wafer. In this work, we assume that the reduction in the interstitial Fe concentration corresponds to the precipitation of $\mathrm{Fe}$.

Note that the images show an apparent increase of $\left[\mathrm{Fe}_{\mathrm{i}}\right]$ directly at the grain boundaries (GBs) and dislocation clusters. It was found in our previous work ${ }^{30}$ that measurement artefacts, due to optical scattering near GBs and photon smearing within the silicon wafers, and to a lesser degree within the CCD-camera, contribute to this apparent increase in $\left[\mathrm{Fe}_{\mathrm{i}}\right]$ at the GBs and dislocation clusters. However, these artefacts are excluded from the analysed regions in this work, and do not impact on the conclusions.

In this section, we will first present results of the areaaveraged interstitial $\mathrm{Fe}$ concentrations across the wafers and compare the Fe precipitation mechanisms of wafers of different initial $\left[\mathrm{Fe}_{\mathrm{i}}\right]$ and with different annealing temperatures. In the second part, we will investigate the spatial distributions of the Fe precipitation across the mc-Si wafers, and the dominant precipitation sites will be identified. In the last part, the 
discrepancy between our results and Krain et al.'s ${ }^{17}$ on the precipitation rate of $\mathrm{Fe}$ in mc-Si wafers, based on area-averaged $\left[\mathrm{Fe}_{\mathrm{i}}\right]$ measurements, will be addressed, and other possible factors affecting the precipitation kinetics will be discussed.

\section{A. Area-averaged precipitation of iron}

The area-averaged interstitial $\mathrm{Fe}$ concentrations across the mc-Si wafers will be used for the following analysis. This is applicable as the comparison of wafers from the two sets of different initial $\left[\mathrm{Fe}_{\mathrm{i}}\right]$ was made only on sister sections which show similar distributions of structural defects. Defect etching of such sister sections confirmed that the two have similar average etch pit densities.

As shown in Fig. 3, the decay of the interstitial Fe concentrations as a function of the annealing time is approximately exponential, except for the last few data points for some data sets, in which a reduced rate of decay is seen. We believe that this is due to significantly reduced degrees of super-saturation, as will be discussed in detail later in this section. A simple exponential decay expression is consistent with Ham's precipitation model for a fixed precipitate radius $^{31,32}$

$$
C(t)-C_{S}=\left(C_{O}-C_{S}\right) \times \exp (-t / \tau)
$$

with

$$
\tau=1 /(4 \pi n r D),
$$

where $C(t)$ is the interstitial $\mathrm{Fe}$ concentration at time $t, C_{S}$ is the $\mathrm{Fe}$ solubility, $C_{O}$ is the initial $\left[\mathrm{Fe}_{\mathrm{i}}\right], \tau$ is the precipitation time constant, $n$ is the precipitation site density, $r$ is the precipitate radius, and $D$ is the $\mathrm{Fe}$ diffusivity.

As more than $90 \%$ of the total $\mathrm{Fe}$ concentration ${ }^{2}$ in the wafers is already in the precipitated state, the growth of the average precipitate radius is likely to be insignificant compared to the average radius of the existing precipitates. Therefore, Ham's expression for fixed precipitate radius (Eq. (1)) is applicable here. In addition, the data can be well fitted by the expression in Eq. (1), as shown in Fig. 3.

For concentrations of interstitial $\mathrm{Fe}$ which are much higher than the Fe solubility limit, for example, at lower temperatures, Eq. (1) can be simplified as

$$
C(t)=C_{O} \times \exp (-t / \tau) .
$$

The expressions in Eqs. (1) and (3) are used to fit the experimental data of $\left[\mathrm{Fe}_{\mathrm{i}}\right]$ versus annealing time for each wafer, and the precipitation time constants extracted from the fitting. For the temperatures below $600{ }^{\circ} \mathrm{C}$, Eqs. (1) and (3) show little difference as fitting curves and hence the simpler form of Eq. (3) is used. For the wafers annealed at $700^{\circ} \mathrm{C}$, especially the high $\left[\mathrm{Fe}_{\mathrm{i}}\right]$ wafer shown in Fig. 3(a), Eq. (1) is required.

The precipitation time constants from Fig. 3 are shown in Fig. 4 as a function of temperature. For the wafers of high initial $\left[\mathrm{Fe}_{\mathrm{i}}\right]$, precipitation was fastest at $600^{\circ} \mathrm{C}$ and slowest at $400^{\circ} \mathrm{C}$; whereas for those of low initial $\left[\mathrm{Fe}_{\mathrm{i}}\right]$, precipitation

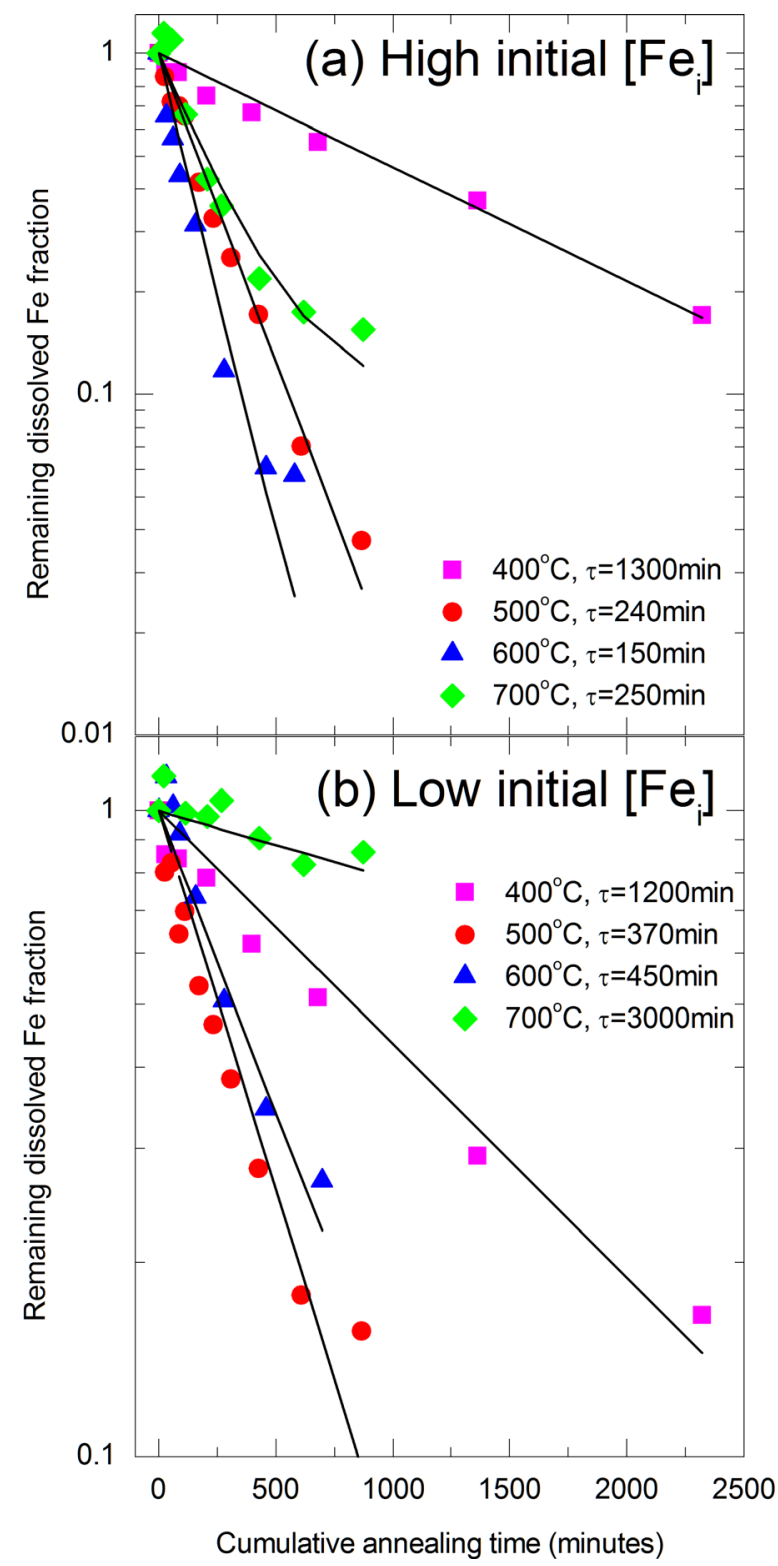

FIG. 3. Remaining dissolved Fe fraction as a function of the annealing time for four groups of sister wafers from the two sample sets-(a): wafers of high initial $\left[\mathrm{Fe}_{\mathrm{i}}\right]$ of around $10^{13} \mathrm{~cm}^{-3}$, (b): low initial $\left[\mathrm{Fe}_{\mathrm{i}}\right]$ of around 3 $\times 10^{12} \mathrm{~cm}^{-3}$. The four groups of sister wafers were annealed at temperatures of $400{ }^{\circ} \mathrm{C}, 500^{\circ} \mathrm{C}, 600^{\circ} \mathrm{C}$, and $700^{\circ} \mathrm{C}$. The experimental data were fitted with the expressions in Eq. (1) or (3).

was fastest at $500^{\circ} \mathrm{C}$ and slowest at $700^{\circ} \mathrm{C}$. For the wafers which have different initial $\mathrm{Fe}_{\mathrm{i}}$ concentrations and were subjected to the same temperature anneals, different precipitation time constants were obtained. The wafers annealed at $400^{\circ} \mathrm{C}$ show similar precipitation time constants for the two of different initial $\left[\mathrm{Fe}_{\mathrm{i}}\right]$; while for the rest annealed at $500-700^{\circ} \mathrm{C}$, the wafers of low initial $\left[\mathrm{Fe}_{\mathrm{i}}\right]$ consistently show larger precipitation time constants than those of higher $\left[\mathrm{Fe}_{\mathrm{i}}\right]$, and the difference becomes more significant as the temperature increases.

The groups of sister wafers have similar densities of structural defects, meaning that they have similar densities of the available precipitation sites. The actual precipitation site density may only be a fraction of the total available precipitations sites, as has been reported for single-crystalline 


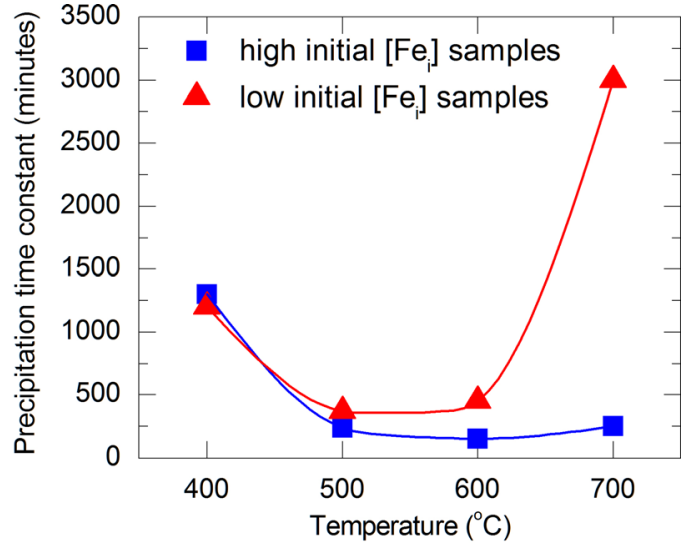

FIG. 4. Precipitation time constants at $400{ }^{\circ} \mathrm{C}-700^{\circ} \mathrm{C}$, for the two sets of wafers of different initial interstitial $\mathrm{Fe}$ concentrations - one with a higher $\left[\mathrm{Fe}_{\mathrm{i}}\right]$ of $10^{13} \mathrm{~cm}^{-3}$ and one with a lower $\left[\mathrm{Fe}_{\mathrm{i}}\right]$ of $3 \times 10^{12} \mathrm{~cm}^{-3}$. The smooth curves are guides to the eyes.

$\mathrm{Cz}$ silicon ${ }^{13,33}$ and polycrystalline silicon, ${ }^{34}$ and implemented in some Fe precipitation models. ${ }^{33,35}$ The average radius of the existing $\mathrm{Fe}$ precipitates, formed during ingot cooling and from feedstock inclusions, ${ }^{4}$ is in theory larger for the higher $\left[\mathrm{Fe}_{\mathrm{i}}\right]$ wafer. This is because wafers of higher $\left[\mathrm{Fe}_{\mathrm{i}}\right]$ reach the $\mathrm{Fe}$ solubility limit at a higher temperature during ingot cooling, giving a longer time for precipitation to occur. As expected from Eq. (2), a larger precipitate size would result in a smaller precipitation time constant. However, if this were the cause for the observed smaller precipitation time constants of the high $\left[\mathrm{Fe}_{\mathrm{i}}\right]$ wafers, its impact would be consistent across all four temperatures, which is in conflict with the results (Fig. 4). Therefore, the differences in the precipitation time constants of the groups of two sister wafers annealed at the same temperatures are not due to either the available precipitation site density, or the initial precipitate size.

Another important difference in the sister wafers which were annealed at the same temperatures is the initial interstitial $\mathrm{Fe}$ concentrations. This leads to differing degrees of super-saturation in the wafers, which could impact on the precipitation kinetics, as was found for $\mathrm{Fe}$ precipitation in $\mathrm{Cz}$ silicon with oxygen precipitates. ${ }^{11,12}$ The degree of super-saturation can be expressed as a saturation ratio, which is the ratio between the interstitial $\mathrm{Fe}$ concentration in the wafer and the Fe solubility $\operatorname{limit}^{36}$ at a given temperature. At the same temperature, wafers of higher $\left[\mathrm{Fe}_{\mathrm{i}}\right]$ have a higher saturation ratio, which may result in faster precipitation of the more super-saturated interstitial Fe atoms. Fig. 5 shows the time-dependent Fe precipitation curves for the wafers annealed at $400-700^{\circ} \mathrm{C}$, as a function of the saturation ratios, which are proportional to the $\mathrm{Fe}_{\mathrm{i}}$ concentrations at a given temperature. The slope of each curve is an indication of the precipitation time constant. As demonstrated in Fig. 5, the effect of super-saturation becomes negligible when the saturation ratios are very high, for example, at $400^{\circ} \mathrm{C}$, where the two curves are parallel to each other (although the reaction proceeds more slowly at this temperature due to the reduced diffusivity of $\mathrm{Fe}$ ). By contrast, the impact of differing

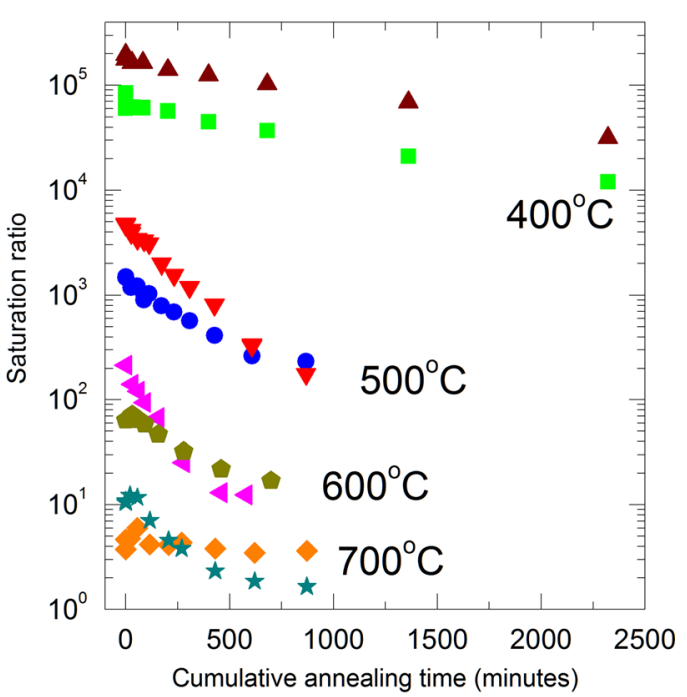

FIG. 5. Saturation ratios, defined as the ratio of $\mathrm{Fe}_{\mathrm{i}}$ concentration in the wafer and the Fe solubility limit at a given temperature, with respect to the cumulative annealing time, of sister wafers of different initial $\mathrm{Fe}_{\mathrm{i}}$ concentrations (high and low initial $\left[\mathrm{Fe}_{\mathrm{i}}\right]$ of $10^{13} \mathrm{~cm}^{-3}$ and $3 \times 10^{12} \mathrm{~cm}^{-3}$, respectively), annealed at $400^{\circ} \mathrm{C}, 500^{\circ} \mathrm{C}, 600^{\circ} \mathrm{C}$, and $700^{\circ} \mathrm{C}$.

amounts of super-saturation becomes increasingly significant as the degree of super-saturation decreases, leading to large variations in the time constants between the two sister wafers.

It is interesting to note that the curves of the two sister wafers which were annealed at $500-700{ }^{\circ} \mathrm{C}$ show "crossover" points. At this point, the saturation ratios of the two are the same. However, wafers of higher initial $\left[\mathrm{Fe}_{\mathrm{i}}\right]$ show faster precipitation after the cross-over points, and the differences in the two slopes increase with increasing temperatures, i.e., decreasing saturation ratios. The initial level of super-saturation in a wafer therefore appears to be an important determinant for how fast Fe precipitates.

The impact of super-saturation on Fe precipitation is not directly expressed in Ham's model. However, the effect of the iron super-saturation may be reflected in the precipitation site density $n$ in Eq. (1), which was found to be only a fraction of the total structural defect density in some studies. ${ }^{13,33,35}$ Moreover, it has been noted ${ }^{12,32,35}$ that Ham's precipitation model is only applicable to the precipitate growth stage, that is, the nucleation process is not considered. The wafers used here already contain a large amount of precipitates prior to the low temperature anneals, and hence the effect of super-saturation may also be related to the energy barriers associated with initiating the process of further precipitate growth.

From the results, we conclude that the optimum temperature for a fast reduction in the interstitial Fe concentration is a balance between high Fe diffusivity at higher temperatures, and a high degree of Fe super-saturation at lower temperatures. The optimum temperature for the fastest internal gettering of $\mathrm{Fe}$ in $\mathrm{mc}-\mathrm{Si}$ therefore varies for wafers of different initial interstitial $\mathrm{Fe}$ concentrations. For the two cases studied here, the optimum precipitation temperature is around $500{ }^{\circ} \mathrm{C}$ for the low $\left[\mathrm{Fe}_{\mathrm{i}}\right]$ samples, and around $600^{\circ} \mathrm{C}$ for the high $\left[\mathrm{Fe}_{\mathrm{i}}\right]$ samples. 


\section{B. Precipitation at grain boundaries and intra-grain regions}

The results presented above are based on the decay of the area-averaged interstitial $\mathrm{Fe}$ concentrations. In this section, the precipitation kinetics are analysed separately for the grain boundaries and the intra-grain regions.

\section{Grain boundaries}

The grain boundaries (GBs) in mc-Si wafers are known to act as gettering sites for interstitial iron. ${ }^{4,19,20}$ This is evidently shown by the appearance of the denuded zones of reduced $\left[\mathrm{Fe}_{\mathrm{i}}\right]$ near $\mathrm{GBs}$ after annealing, and the widening of the denuded zones with accumulating annealing times, as can be seen by comparing the $\left[\mathrm{Fe}_{\mathrm{i}}\right]$ images in Fig. 1. This effect can be seen more easily in Fig. 6, which shows [Fe $\left.\mathrm{Fe}_{\mathrm{i}}\right]$ profiles across the same GB after different annealing times.

As we have shown in previous work, the $\left[\mathrm{Fe}_{\mathrm{i}}\right]$ profiles across a GB can be well fitted by a diffusion-capture model, ${ }^{19}$ which has two fitting parameters-the diffusion length of interstitial $\mathrm{Fe}$ atoms, and the gettering velocity, or precipitation velocity, at the GB. This parameter is analogous to the surface recombination velocity for excess carriers recombining at wafer surfaces. ${ }^{19}$ This diffusion-capture model is fitted to the Fe profiles in Fig. 6. Note that the diffusion lengths of $\mathrm{Fe}$ extracted from the fits agree very well with those calculated from the known Fe diffusivity from the literature, ${ }^{37}$ and the annealing time, according to $L_{D}=\sqrt{D t}$, as shown in Fig. 7.

Fig. 6 also shows a comparison of the experimental $\left[\mathrm{Fe}_{\mathrm{i}}\right]$ profile after 430 min annealing, with two modelled cases: one assuming an infinite gettering velocity at the GB (dashed line), and another with a finite gettering velocity of $2.5 \times 10^{-6} \mathrm{~cm} / \mathrm{s}$ (solid line). In both cases, the $\mathrm{Fe}$ diffusion

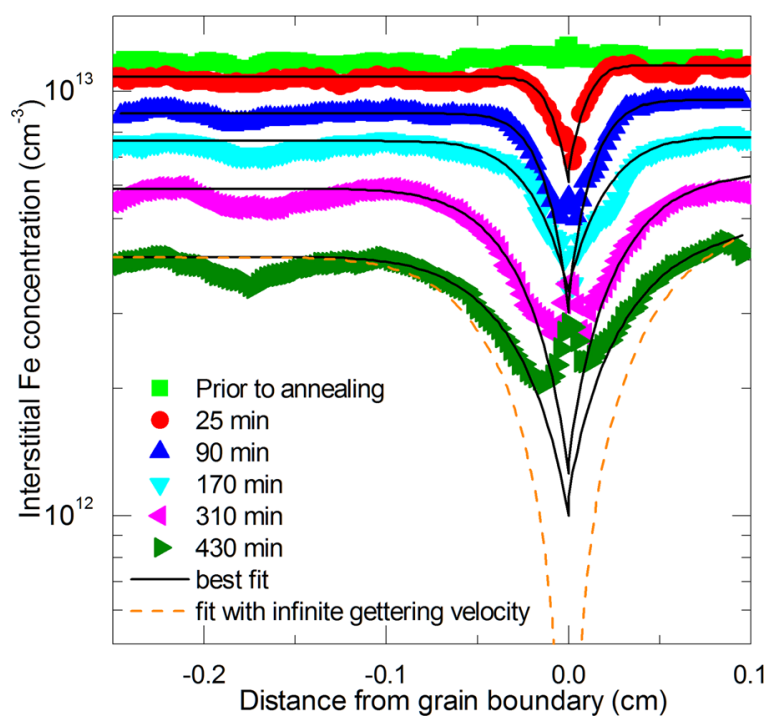

FIG. 6. Interstitial Fe concentration profiles across the same grain boundary of a wafer which was annealed at $500^{\circ} \mathrm{C}$ for various times. The experimental data were obtained by taking linescans across the GB on the $\left[\mathrm{Fe}_{\mathrm{i}}\right]$ images. The smooth lines represent fitting to the experimental data using an iron diffusion-capture model. A modelled profile using the expected diffusion length of $\mathrm{Fe}$ (from the annealing temperature and time) and an infinite gettering velocity at the GB is also shown for the $430 \mathrm{~min}$ annealed data.

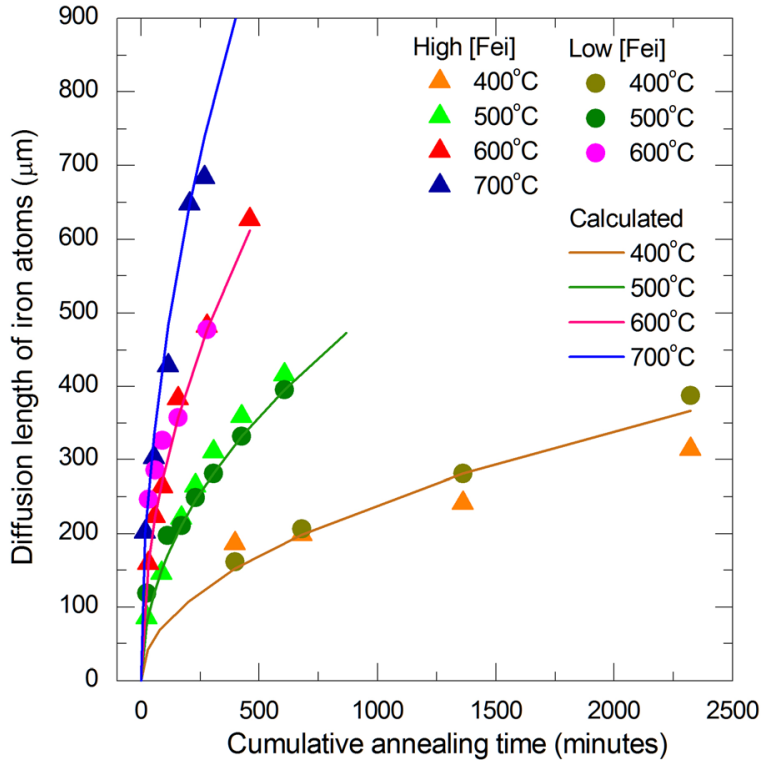

FIG. 7. Diffusion lengths of Fe atoms estimated from fitting the experimental linescans with a diffusion-capture model (symbols), and calculated from the known Fe diffusivity and annealing times (lines).

length is fixed at $335 \mu \mathrm{m}$, the value expected form the known diffusivity of $\mathrm{Fe}$ at this temperature and for this annealing time. The results clearly show that the GB does not act as an infinite sink for Fe precipitation. This implies that the precipitation of $\mathrm{Fe}$ at the GBs is not only a diffusion-limited process but is also limited to some extent by the capture rate. The capture process, i.e., Fe precipitation, is characterised by the gettering velocity at the GB.

The gettering velocity of comparable GBs shows large temperature dependence, as illustrated in Fig. 8. The gettering velocity increases from $400{ }^{\circ} \mathrm{C}$ to $600{ }^{\circ} \mathrm{C}$, for both sets of the wafers of different initial $\mathrm{Fe}_{\mathrm{i}}$ concentrations. For the set of wafers with high initial $\left[\mathrm{Fe}_{\mathrm{i}}\right]$, the gettering velocity is found to decrease slightly from $600^{\circ} \mathrm{C}$ to $700{ }^{\circ} \mathrm{C}$; whereas for the low initial $\left[\mathrm{Fe}_{\mathrm{i}}\right]$ wafers, denuded zones could not be identified as very little reduction in $\left[\mathrm{Fe}_{\mathrm{i}}\right]$ is found at $700{ }^{\circ} \mathrm{C}$ near the GBs, as a result of a low degree of super-saturation. The increasing trend of the gettering velocity from $400{ }^{\circ} \mathrm{C}$ to $600^{\circ} \mathrm{C}$ indicates that the rate at which $\mathrm{Fe}$ precipitation occurs at the GBs increases with temperature. This is in contrary to the expected effect of super-saturation on Fe precipitation, since a higher level of super-saturation (i.e., a lower temperature for a given $\mathrm{Fe}_{\mathrm{i}}$ concentration) would result in more effective precipitation. In addition, at the same temperatures, the two sets of wafers give similar values of gettering velocity, despite being under different levels of super-saturation. The effect of super-saturation is therefore not a dominating determinant in how effectively $\mathrm{Fe}$ is gettered at the GBs, for temperatures below $600{ }^{\circ} \mathrm{C}$ (saturation ratios well above 10 ). At $700^{\circ} \mathrm{C}$ when the saturation ratios are small, the impact of super-saturation again plays a role, as a less effective precipitation than that at $600^{\circ} \mathrm{C}$ is observed for the wafers of high initial $\left[\mathrm{Fe}_{\mathrm{i}}\right]$, and no precipitation could be seen for the low $\left[\mathrm{Fe}_{\mathrm{i}}\right]$ wafers.

The reduced importance of super-saturation on the Fe precipitation at the GBs may be related to the fact that Fe 


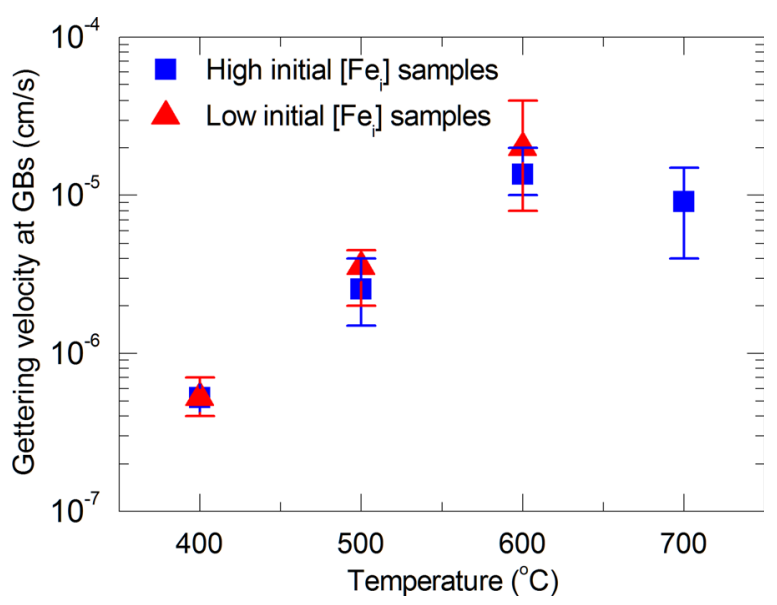

FIG. 8. Gettering velocity at recombination active grain boundaries with denuded zones, estimated from fitting the experimental $\left[\mathrm{Fe}_{\mathrm{i}}\right]$ profiles with a diffusion-capture model, plotted against the annealing temperatures, for both high and low initial $\left[\mathrm{Fe}_{\mathrm{i}}\right]$ wafers.

precipitates are likely to already exist close to the GBs prior to the low temperature anneals. ${ }^{4}$ There is likely to be a lower barrier to the further growth of an existing precipitate, compared to the nucleation of new precipitates. It is plausible that the increased barrier for the nucleation of new precipitates requires a greater degree of super-saturation to be overcome. Once started, precipitation can then proceed with a reduced dependence on the saturation ratio. This is supported by the effect of the initial saturation ratios on the Fe precipitation kinetics for the area-averaged Fe concentrations, discussed in Sec. III A.

The different impact of super-saturation on Fe precipitation between the GBs and the overall behaviour of area-averaged mc-Si wafers implies that the amount of $\mathrm{Fe}$ precipitated at the GBs only accounts for a small fraction of the total amount of precipitated Fe during the low temperature annealing. The majority of the Fe precipitation occurs within the grains, and this will be discussed in Sec. III B 2 .

We note that not all grain boundaries were found to act as precipitation sites for $\mathrm{Fe}$. The twin boundaries, for example, demonstrate no gettering effect. Such twin boundaries are also not recombination active as revealed by the PL images. This has been reported previously. ${ }^{38}$

\section{Intra-grain regions}

The interstitial $\mathrm{Fe}$ concentrations are reduced not only near the grain boundaries but also within the grains after the low temperature anneals, as can be seen in Figs. 1 and 6 at distances far from the GBs. The Fe precipitation time constants of the intra-grains may vary across different grains within one mc-Si wafer or even different regions within one grain. Fig. 9 presents the reduction trends of several intragrain regions as a function of annealing time at $500^{\circ} \mathrm{C}$, for the regions shown in Fig. 1(d). A large variation in the precipitation time constants can be seen.

Some of the wafers were etched to reveal the distributions of dislocations and grain boundaries, and the interstitial Fe concentrations after annealing for a fixed, long time are plotted in Fig. 10 as a function of the average dislocation

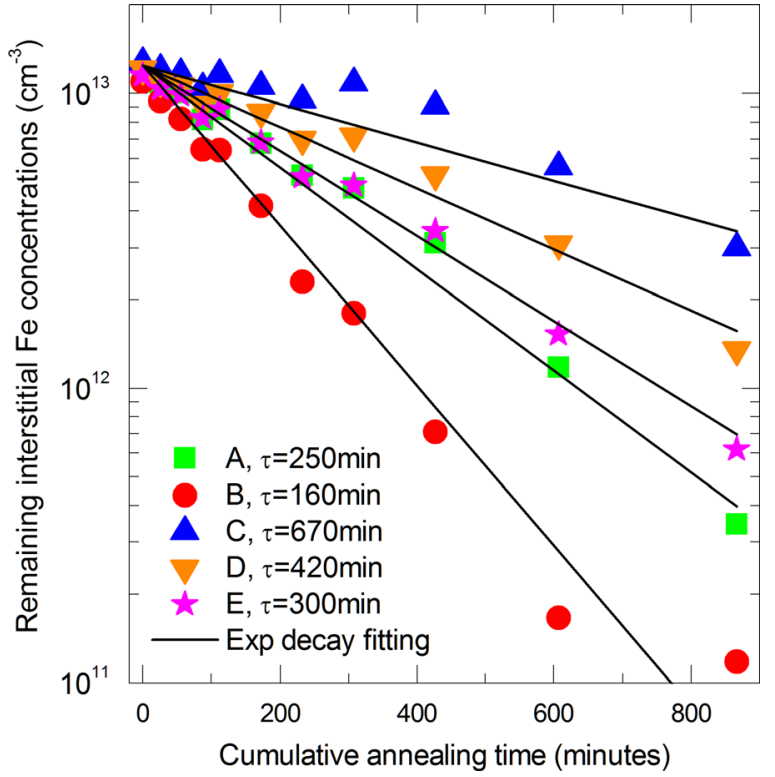

FIG. 9. Remaining interstitial Fe concentrations as a function of cumulative annealing time for a wafer annealed at $500^{\circ} \mathrm{C}$. Five different intra-grain regions were chosen, the positions of which are labelled in Fig. 1(d). Note that Regions D and $\mathrm{E}$ are located in one grain.

densities of the intra-grain regions. The $\left[\mathrm{Fe}_{\mathrm{i}}\right]$ after annealing for a sufficiently long time is taken an indication of how fast Fe precipitates, because the initial $\left[\mathrm{Fe}_{\mathrm{i}}\right]$ prior to annealing is uniform across the mc-Si wafer, as can be seen in Fig. 1(a). Data for anneals at 500 and $700{ }^{\circ} \mathrm{C}$ are shown. To allow a fair comparison between these, anneal times corresponding to diffusion lengths of $\mathrm{Fe}$ atoms during the annealing processes of around $330 \mu \mathrm{m}$ were chosen. The annealing times are $430 \mathrm{~min}$ and $55 \mathrm{~min}$ for the $500^{\circ} \mathrm{C}$ and $700^{\circ} \mathrm{C}$ anneals, respectively. Note that the distance between the chosen intra grain regions and the GBs is much greater than this diffusion length of $\mathrm{Fe}$, in order to exclude the effect of gettering by the nearby GBs on the measured intra-grain $\mathrm{Fe}_{\mathrm{i}}$ concentrations.

The results in Fig. 10 demonstrate a decreasing trend of the remaining $\left[\mathrm{Fe}_{\mathrm{i}}\right]$ with increasing dislocation density. That is, regions of higher dislocation density have reduced interstitial $\mathrm{Fe}$ concentrations after annealing for a fixed time, meaning that more $\mathrm{Fe}$ is precipitated during annealing. The average distance between dislocations, as calculated from the measured dislocation densities, is about $25-70 \mu \mathrm{m}$, which is much smaller than the diffusion length of Fe during annealing (Fig. 7). Therefore, the denuded zones of reduced $\left[\mathrm{Fe}_{\mathrm{i}}\right]$ could not be clearly identified for the intra-grain dislocations. As iron is known to precipitate heterogeneously in silicon, ${ }^{39}$ this result indicates that the intra-grain dislocations act as the precipitation sites for the interstitial $\mathrm{Fe}$ atoms.

We note that the silicon oxide layers on the surfaces of the wafers are unlikely to be a major source of precipitation sites for $\mathrm{Fe}$ in the mc-Si wafers examined here, because it was found that the precipitation time constants of the intragrain regions show a large variation within the same grains. If surface precipitation was dominant, each grain would demonstrate a uniform rate of decay in $\mathrm{Fe}_{\mathrm{i}}$ concentration. An example of the different precipitation time constants is illustrated in Fig. 9, where the regions D and $\mathrm{E}$ are from the same 


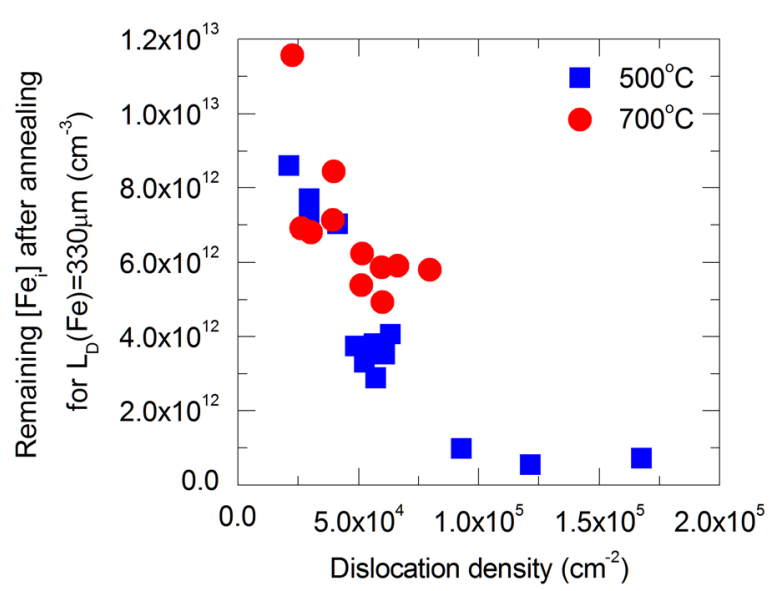

FIG. 10. Interstitial Fe concentrations after annealing, averaged across intragrain regions of different dislocation densities, for two wafers annealed at $500{ }^{\circ} \mathrm{C}$ and $700^{\circ} \mathrm{C}$, respectively. To compare the two of different temperature anneals, the $\mathrm{Fe}_{\mathrm{i}}$ concentrations were taken after annealing for time durations such that the diffusion length of $\mathrm{Fe}$ atoms is around $330 \mu \mathrm{m}$.

grain as denoted in Fig. 1(d). More examples can be seen in Fig. 1(d), illustrated by the varying $\mathrm{Fe}_{\mathrm{i}}$ concentrations across some of the same grains.

In previous work by Murphy and Falster, ${ }^{40}$ the reduction of $\left[\mathrm{Fe}_{\mathrm{i}}\right]$ after low temperature annealing in high-purity $\mathrm{Cz}$ silicon wafers with no pre-existing iron silicides on the surface was thought to be due to the precipitation at bulk voids. The precipitation time constants deduced from their data at $550-700{ }^{\circ} \mathrm{C}$ are in the order of tens of hours, which are much larger than our findings. Thus, the bulk voids do not act as a dominating type of precipitation sites in the mc-Si wafers studied here.

To summarise, dislocations are likely the dominating precipitation sites at the intra-grain regions of $\mathrm{mc}-\mathrm{Si}$. As a result of the different dislocation densities and the heterogeneous precipitation nature of iron, ${ }^{39}$ a large variation in the precipitation time constants can be seen across the intragrains of a mc-Si wafer. Some of the grain boundaries are also shown to act as precipitation sites for iron, creating denuded zones of reduced interstitial iron concentrations near the GBs. The internal gettering of iron by the GBs is limited by both the diffusion of iron and the gettering efficacy at the GBs. The gettering efficacy at the GBs is found to increase with temperature, unless a very low degree of iron super-saturation (below a factor of ten) is present to hinder the precipitation process. The internal gettering effect of both the dislocations and the grain boundaries is reflected in the overall reduction in the interstitial iron concentrations across a mc-Si wafer, shown by the area-averaged $\left[\mathrm{Fe}_{\mathrm{i}}\right]$ decay with annealing time.

\section{Other factors affecting iron precipitation}

The area-averaged iron precipitation time constants of the mc-Si wafers examined in this paper, as summarised in Fig. 4, are an order of magnitude larger than those reported by Krain et al. ${ }^{17}$ at the overlapping temperatures. In this section, we will discuss the possible explanations for this large discrepancy.
The mc-Si wafers used in Krain et al. ${ }^{17}$ had an initial interstitial Fe concentration of $10^{12} \mathrm{~cm}^{-3}$ for the $400{ }^{\circ} \mathrm{C}$ and $500{ }^{\circ} \mathrm{C}$ anneals, which is lower than that of the mc-Si wafers used in this study $-10^{13} \mathrm{~cm}^{-3}$ and $3 \times 10^{12} \mathrm{~cm}^{-3}$ for the high and low $\left[\mathrm{Fe}_{\mathrm{i}}\right]$ samples, respectively. The higher levels of super-saturation in our samples should therefore result in even faster Fe precipitation compared to Krain et al.'s, which is contrary to our findings. Thus, the level of super-saturation cannot explain the discrepancy.

In Ref. 17, the area-averaged interstitial Fe concentrations were determined from the minority carrier lifetimes measured by the QSSPC technique. In this study, the lifetimes were obtained by calibrating the PL signals with the in-built QSSPC device in the PL imager. Reasonable agreement of the resulting $\mathrm{Fe}_{\mathrm{i}}$ concentrations was found in our previous study. ${ }^{23}$ Some of the wafers were measured using both the PL imager and the QSSPC lifetime tester. The results show that the $\mathrm{Fe}$ precipitation time constants derived from the PL $\left[\mathrm{Fe}_{\mathrm{i}}\right]$ images are consistent with the QSSPC measurements. The different measurement techniques can therefore also be excluded as the reason for this discrepancy.

One of the possible explanations may be the differences in the density of the crystallographic defects and other precipitation sites of the mc-Si wafers examined in the two studies. For example, as shown in Fig. 10, the Fe precipitation time constants are dependent on the dislocation density. If the wafers used in Krain et al. are from very bottom of the ingot, for instance, a high concentration of structural defects and oxygen precipitates are expected, which would result in faster precipitation of Fe.

The discrepancy may also be caused by the effect of hydrogenation on the interstitial $\mathrm{Fe}$ concentrations in $\mathrm{mc}-\mathrm{Si}$ wafers. It has been reported ${ }^{41-44}$ that a reduced concentration of interstitial $\mathrm{Fe}$ is measured after hydrogen being introduced into the mc-Si bulk. A recent study ${ }^{41}$ shows that the apparent decay in $\left[\mathrm{Fe}_{\mathrm{i}}\right]$ is faster in the hydrogenated wafers. In Krain et al.'s study, ${ }^{17}$ silicon nitride films from plasma enhanced chemical vapour deposition (PECVD) were used as the surface passivation layers. It is not clear from Krain et al. ${ }^{17}$ whether or not the silicon nitride films were removed and re-passivated after each annealing step at $300-500{ }^{\circ} \mathrm{C}$. If the silicon nitride films were present during the low temperature anneals, hydrogenation of the bulk defects could be expected. ${ }^{45-48}$ The PL images of the wafer before and after annealing as shown in Ref. 17 show reduced recombination activity of some of the GBs and dislocation clusters after annealing, which is an indication that hydrogenation was present.

On the other hand, the wafers tested in this paper do not show such an effect of reduced recombination activity at the structural defects on the PL images after annealing. The wafers were previously oxidised at a high temperature of $1000^{\circ} \mathrm{C}$, and as reported in Ref. 49, activation of some defects is expected and such defects would be hydrogenated more easily. This is however not observed. In addition, in a previous experiment ${ }^{18}$ the precipitation of Fe was tested on mc-Si wafers, which were annealed in oxygen at low temperatures; and then with the silicon oxide layers removed, the wafers were re-passivated with silicon nitride using PECVD. 
The wafers were subjected to no further temperature processes, and thus the hydrogenation effect was not activated, which is also confirmed by the PL images. The precipitation time constant estimated from this study ${ }^{18}$ shows a reasonable agreement with the findings of this paper, despite different gas ambient at low temperature annealing being used in the two experiments. Hydrogenation of the bulk defects is therefore unlikely in our samples.

To test the hypothesis that the slower precipitation observed in this paper is due to the absence of the hydrogenation effect, aluminium oxide films were used for surface passivation, as the films contain a small amount of hydrogen $^{50}$ and reasonable stability is maintained after annealing at $400{ }^{\circ} \mathrm{C}$ (as shown in Fig. 2). A previously oxidised mc-Si wafer of low initial $\left[\mathrm{Fe}_{\mathrm{i}}\right]$ was re-passivated with aluminium oxide films after removing the thermally grown silicon oxide layers, and the wafer was annealed at $400{ }^{\circ} \mathrm{C}$ for cumulative times. Imaging of the interstitial $\mathrm{Fe}$ concentrations was conducted after each annealing step as was done for the silicon oxide passivated samples. Comparison of the PL images before and after the $\mathrm{Al}_{2} \mathrm{O}_{3}$ coating and the $400{ }^{\circ} \mathrm{C}$ anneals shows a small degree of hydrogenation effect at some of the GBs and dislocation clusters. The hydrogenation effect of $\mathrm{Al}_{2} \mathrm{O}_{3}$ films has also been observed previously. ${ }^{51}$ The reduction in the $\left[\mathrm{Fe}_{\mathrm{i}}\right]$ of the $\mathrm{Al}_{2} \mathrm{O}_{3}$ coated mc-Si wafer is much faster, with an iron precipitation time constant of $210 \mathrm{~min}$, in comparison with the 1300 min found for the $\mathrm{SiO}_{2}$ passivated sample of the same initial $\left[\mathrm{Fe}_{\mathrm{i}}\right]$, as shown in Fig. 11. The precipitation time constant at $400{ }^{\circ} \mathrm{C}$ found in Krain et al.'s data is $100 \mathrm{~min}$. The silicon nitride passivation films are known to have a higher content of hydrogen than the aluminium oxide films, ${ }^{50,52}$ and this may explain the faster reduction in $\left[\mathrm{Fe}_{\mathrm{i}}\right]$ of the sample with the silicon nitride films. ${ }^{41}$ Therefore, the lack of hydrogen in our mc-Si wafers may explain the slower precipitation processes found in this paper compared to Krain et al.'s, ${ }^{17}$ although the physical mechanism behind this behaviour is not yet clear.

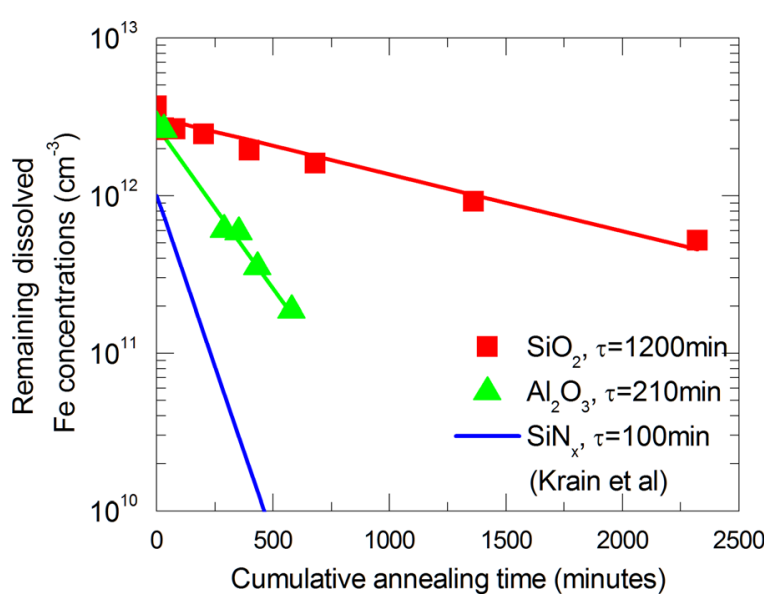

FIG. 11. Remaining isolated dissolved interstitial Fe concentrations plotted against cumulative annealing time for wafers annealed at $400^{\circ} \mathrm{C}$, but with different passivation layers-silicon oxide, aluminium oxide, and silicon nitride (taken from Krain et al. ${ }^{17}$ ).

\section{CONCLUSION}

The precipitation of iron in multicrystalline silicon has been systematically studied, based on the analysis of the changes in the concentrations and distributions of interstitial $\mathrm{Fe}$ in mc-Si wafers annealed at $400-700^{\circ} \mathrm{C}$. The Fe precipitation kinetics is examined as a function of the annealing time, temperature, super-saturation level, and precipitation sites. A significant reduction in the interstitial Fe concentrations by more than one order of magnitude is observed for the mc-Si wafers annealed at these low temperatures. The concentrations of the remaining $\mathrm{Fe}_{\mathrm{i}}$ with respect to the annealing time is well fitted by Ham's precipitation model of fixed precipitate radius, which can be simplified as an exponential decay function for lower temperatures. The average $\mathrm{Fe}$ precipitation time constants of the mc-Si wafers were found to vary with annealing temperatures, as well as depending strongly on the initial $\mathrm{Fe}_{i}$ concentrations. The level of Fe super-saturation is therefore identified as one of the key determinants for the rate of $\mathrm{Fe}$ precipitation. A higher degree of Fe super-saturation is shown to result in a faster precipitation process, unless the super-saturation levels are so high (above 1000) that its impact is saturated. The optimum temperature for rapid $\left[\mathrm{Fe}_{\mathrm{i}}\right]$ reduction is therefore a compromise between high $\mathrm{Fe}$ diffusivity and high super-saturation level, and varies for wafers of different initial $\mathrm{Fe}_{\mathrm{i}}$ concentrations.

The spatially resolved $\mathrm{Fe}_{\mathrm{i}}$ images allow us to assess the precipitation kinetics at the grain boundaries and the intra-grains separately. Some grain boundaries are shown to be effective precipitation sites for Fe during low temperature annealing. The precipitation of Fe in the close vicinity of the GBs is found to increase with temperature and is less affected by the degree of $\mathrm{Fe}$ super-saturation. The reduction in the $\mathrm{Fe}_{\mathrm{i}}$ concentrations also occurs within the grains, and the precipitation time constants are shown to vary across different grains as well as across different regions of the same grains. The precipitation rate is found to increase with increasing dislocation density of the intra-grain regions, suggesting that the dislocations are a major type of precipitation sites in $\mathrm{mc}-\mathrm{Si}$.

The discrepancy in the precipitation time constants observed in this paper and in Krain et al.'s is possibly related to the different densities of precipitation sites (crystallographic defects and etc.) in the mc-Si wafers being used, and/or perhaps the effect of bulk hydrogenation on the measured concentrations of interstitial iron in multicrystalline silicon.

\section{ACKNOWLEDGMENTS}

This work was supported by the Australian Research Council. The authors would like to thank S. P. Phang, H. C. Sio, and D. Yan for assistance with sample processing. D. Walter is acknowledged for the supply of the point-spreadfunction used for image de-convolution. We would also like to acknowledge fruitful discussions with the following colleagues: S. P. Phang, H. C. Sio, and W. Liang of the Australian National University, and Dr. J. Schon and F. Heinz of the Fraunhofer Institute for Solar Energy Systems. 
${ }^{1}$ A. A. Istratov, H. Hieslmair, and E. R. Weber, Appl. Phys. A 70, 489-534 (2000).

${ }^{2}$ D. Macdonald, A. Cuevas, A. Kinomura, Y. Nakano, and L. J. Geerligs, J. Appl. Phys. 97, 033523 (2005).

${ }^{3}$ A. A. Istratov, T. Buonassisi, R. J. McDonald, A. R. Smith, R. Schindler, J. A. Rand, J. P. Kalejs, and E. R. Weber, J. Appl. Phys. 94, 6552-6559 (2003).

${ }^{4}$ T. Buonassisi, A. A. Istratov, M. Heuer, M. A. Marcus, R. Jonczyk, J. Isenberg, B. Lai, Z. Cai, S. Heald, W. Warta, R. Schindler, G. Willeke, and E. R. Weber, J. Appl. Phys. 97, 074901 (2005).

${ }^{5}$ T. Buonassisi, A. A. Istratov, M. D. Pickett, J. P. Rakotoniaina, O. Breitenstein, M. A. Marcus, S. M. Heald, and E. R. Weber, J. Cryst. Growth 287, 402-407 (2006).

${ }^{6}$ R. Kvande, L. Arnberg, and C. Martin, J. Cryst. Growth 311, 765-768 (2009).

${ }^{7}$ P. Gundel, M. C. Schubert, F. D. Heinz, W. Kwapil, W. Warta, G. Martinez-Criado, M. Reiche, and E. R. Weber, J. Appl. Phys. 108, 103707 (2010).

${ }^{8}$ S. P. Phang and D. Macdonald, J. Appl. Phys. 109, 073521 (2011).

${ }^{9}$ P. Manshanden and L. J. Geerligs, Sol. Energy Mater. Sol. Cells 90, 998-1012 (2006).

${ }^{10}$ D. Gilles, E. R. Weber, and S. Hahn, Phys. Rev. Lett. 64, 196-199 (1990).

${ }^{11}$ M. Aoki, A. Hara, and A. Ohsawa, J. Appl. Phys. 72, 895-898 (1992).

${ }^{12}$ A. Haarahiltunen, H. Vainola, O. Anttila, M. Yli-Koski, and J. Sinkkonen, J. Appl. Phys. 101, 043507 (2007).

${ }^{13}$ H. Hieslmair, A. A. Istratov, S. A. McHugo, C. Flink, T. Heiser, and E. R. Weber, Appl. Phys. Lett. 72, 1460-1462 (1998).

${ }^{14}$ M. D. Pickett and T. Buonassisi, Appl. Phys. Lett. 92, 122103 (2008).

${ }^{15}$ M. Rinio, A. Yodyunyong, S. Keipert-Colberg, Y. P. B. Mouafi, D. Borchert, and A. Montesdeoca-Santana, Prog. Photovoltaics 19, 165-169 (2011).

${ }^{16}$ M. Rinio, A. Yodyungyong, S. Keipert-Colberg, D. Borchert, and A. Montesdeoca-Santana, Physica Status Solidi A 208, 760-768 (2011).

${ }^{17}$ R. Krain, S. Herlufsen, and J. Schmidt, Appl. Phys. Lett. 93, 152108 (2008).

${ }^{18}$ A. Y. Liu, D. Walter, and D. Macdonald, in The 22nd International Photovoltaic Science and Engineering Conference (Hang Zhou, China, 2012).

${ }^{19}$ A. Y. Liu, D. Walter, S. P. Phang, and D. Macdonald, IEEE J. Photovolt. 2, 479-484 (2012).

${ }^{20}$ M. Seibt, V. Kveder, W. Schröter, and O. Voß, Phys. Status Solidi A 202, 911-920 (2005).

${ }^{21}$ T. Trupke, R. A. Bardos, M. C. Schubert, and W. Warta, Appl. Phys. Lett. 89, 044107 (2006).

${ }^{22}$ D. Macdonald, J. Tan, and T. Trupke, J. Appl. Phys. 103, 073710 (2008).

${ }^{23}$ A. Y. Liu, Y. C. Fan, and D. Macdonald, Prog. Photovoltaics 19, 649-657 (2011).

${ }^{24}$ T. Buonassisi, A. A. Istratov, S. Peters, C. Ballif, J. Isenberg, S. Riepe, W. Warta, R. Schindler, G. Willeke, Z. Cai, B. Lai, and E. R. Weber, Appl. Phys. Lett. 87, 121918 (2005).

${ }^{25}$ D. Macdonald, A. Y. Liu, and S. P. Phang, Solid State Phenom. 205-206, 26-33 (2013)

${ }^{26}$ G. Zoth and W. Bergholz, J. Appl. Phys. 67, 6764-6771 (1990).
${ }^{27}$ R. A. Sinton and A. Cuevas, Appl. Phys. Lett. 69, 2510-2512 (1996).

${ }^{28}$ D. Walter, A. Y. Liu, E. Franklin, D. Macdonald, B. Mitchell, and T. Trupke, in 38th IEEE Photovoltaic Specialists Conference (PVSC) (2012), pp. 000307-000312.

${ }^{29}$ Y. Kashiwagi, R. Shimokawa, and M. Yamanaka, J. Electrochem. Soc. 143, 4079-4087 (1996).

${ }^{30}$ A. Y. Liu, D. Walter, S. P. Phang, and D. Macdonald, in 38th IEEE Photovoltaic Specialists Conference (PVSC) (2012), pp. 000248-000253.

${ }^{31}$ F. S. Ham, J. Phys. Chem. Solids 6, 335-351 (1958).

${ }^{32}$ H. Hieslmair, A. A. Istratov, T. Heiser, and E. R. Weber, J. Appl. Phys. 84, 713-717 (1998).

${ }^{33}$ A. Haarahiltunen, M. Yli-Koski, H. Väinölä, M. Palokangas, E. Saarnilehto, and J. Sinkkonen, Phys. Scr. 2004, 91-93.

${ }^{34}$ J. Bailey and E. R. Weber, Phys. Status Solidi A 137, 515-523 (1993).

${ }^{35}$ J. Schon, H. Habenicht, M. C. Schubert, and W. Warta, J. Appl. Phys. 109, 063717 (2011).

${ }^{36}$ J. D. Murphy and R. J. Falster, Phys. Status Solidi RRL 5, 370-372 (2011).

${ }^{37}$ A. A. Istratov, H. Hieslmair, and E. R. Weber, Appl. Phys. A 69, 13-44 (1999).

${ }^{38}$ J. Chen, T. Sekiguchi, D. Yang, F. Yin, K. Kido, and S. Tsurekawa, J. Appl. Phys. 96, 5490-5495 (2004).

${ }^{39}$ K. Graff, Mater. Sci. Eng. B 4, 63-69 (1989).

${ }^{40}$ J. D. Murphy and R. J. Falster, J. Appl. Phys. 112, 113506 (2012).

${ }^{41}$ P. Karzel, A. Frey, S. Fritz, and G. Hahn, J. Appl. Phys. 113, 114903 (2013).

${ }^{42}$ L. Geerligs, A. Azzizi, D. Macdonald, and P. Manshanden, in 13th Workshop on Crystalline Silicon Solar Cell Materials and Processes (Vail, Colorado, 2003), pp. 199-202.

${ }^{43}$ H. Habenicht, M. C. Schubert, A. Richter, and W. Warta, in 24th European PV Solar Energy Conference and Exhibition (Hamburg, Germany, 2009), pp. 2266-2269.

${ }^{44} \mathrm{~K}$. McLean, C. Morrow, and D. Macdonald, in Conference Record of the 2006 IEEE 4th World Conference on Photovoltaic Energy Conversion (2006), Vol. 1, pp. 1122-1125.

${ }^{45}$ B. L. Sopori, X. Deng, J. P. Benner, A. Rohatgi, P. Sana, S. K. Estreicher, Y. K. Park, and M. A. Roberson, Sol. Energy Mater. Sol. Cells 41-42, 159-169 (1996).

${ }^{46}$ F. Duerinckx and J. Szlufcik, Sol. Energy Mater. Sol. Cells 72, 231-246 (2002).

${ }^{47}$ S. Martinuzzi, I. Périchaud, and F. Warchol, Sol. Energy Mater. Sol. Cells 80, 343-353 (2003).

${ }^{48}$ S. J. Pearton, J. W. Corbett, and T. S. Shi, Appl. Phys. A 43, 153-195 (1987).

${ }^{49}$ L. J. Geerligs, Y. Komatsu, I. Rover, K. Wambach, I. Yamaga, and T. Saitoh, J. Appl. Phys. 102, 093702 (2007).

${ }^{50}$ M. D. Groner, F. H. Fabreguette, J. W. Elam, and S. M. George, Chem. Mater. 16, 639-645 (2004).

${ }^{51}$ H. C. Sio, S. P. Phang, Y. Wan, W. Liang, T. Trupke, S. Cao, D. Hu, Y. Wan, and D. Macdonald, in 39th IEEE Photovoltaic Specialists Conference (Tampa, Florida, 2013).

${ }^{52}$ H. F. W. Dekkers, G. Beaucarne, M. Hiller, H. Charifi, and A. Slaoui, Appl. Phys. Lett. 89, 211914 (2006). 